\title{
Identifikasi Penyakit Bercak Daun Coklat dan Busuk Umbi pada Tanaman Ubikayu (Manihot esculenta Crantz) akibat Penambahan Pupuk KCl dan "Zincmicro"
}

\author{
Identification of brown leaf spot and tuber rot disease in cassava plants \\ (Manihot esculenta Crantz) due to addition of KCl fertilizer and "Zincmicro" \\ Cemi Wulan Miarti ${ }^{1 *}$, Efri $^{1}$, Muhammad Syamsoel Hadi $^{1}$, Radix Suharjo ${ }^{1}$ \\ 1 Jurusan Agroteknologi, Fakultas Pertanian, Universitas Lampung. \\ Jl. Sumantri Brojonegoro 1, Bandar Lampung, 35145, Lampung, Indonesia \\ *Email:cemi.wulan97@gmail.com
}

\begin{abstract}
Abstrak: Penelitian ini bertujuan untuk mengetahui pengaruh penambahan pupuk $\mathrm{KCl}$ dan ZincMicro pada tanaman ubikayu (Manihot esculenta Crantz) terhadap keparahan penyakit bercak daun coklat (Cercospora henningsii), keterjadian penyakit busuk umbi. Penelitian ini dilakukan mulai bulan April 2018 hingga Februari 2019 di Desa Sukanegara, Kecamatan Tanjung Bintang, Kabupaten Lampung Selatan dan di Laboratorium Bioteknologi, Fakultas Pertanaian, Universitas Lampung. Rancangan percobaan yang digunakan adalah Rancangan Tersarang (ulangan tersarang dalam perlakuan) yang terdiri dari 4 perlakuan yaitu $A$. dosis sesuai kebiasaan petani (200 $\mathrm{kg} \mathrm{KCl} \mathrm{ha}^{-1}$ ), B. peningkatan dosis $\mathrm{KCl}$ menjadi $300 \mathrm{~kg} \mathrm{KCl} \mathrm{ha}^{-1}$, C. A + penambahan $20 \mathrm{~kg}$ ZincMicro ha- ${ }^{-1}$, dan D. B + penambahan $20 \mathrm{~kg}$ ZincMicro ha $^{-1}$. Hasil penelitian menunjukkan bahwa aplikasi pupuk $\mathrm{KCl}$ dengan penambahan ZincMicro mampu menekan keparahan penyakit bercak daun coklat (Cercospora henningsii). Penambahan pupuk $\mathrm{KCl}$ dan ZincMicro tidak mampu menekankan keterjadian penyakit busuk umbi.
\end{abstract}

Kata kunci: Bercak daun coklat, KCl, ubikayu, ZincMicro.

Abstract: This research aims to investigate the effect of addition of $\mathrm{KCl}$ and ZincMicro fertilizer on cassava plant (Manihot esculenta Crantz) for the severity of brown leaf spot disease (Cercospora henningsii), the incidence of tuber rot disease. This research was conducted from April 2018 to February 2019 in the Sukanegara Village, Tanjung Bintang Sub-district, South Lampung, Lampung Province and in the Biotechnology Laboratory, Faculty of Agriculture, University of Lampung. The experimental design used was a nested design (repeated nested treatment) that consisted of 4 treatments of $A$. dosage according to farmer's habits $\left(200 \mathrm{~kg} \mathrm{KCl} \mathrm{ha}{ }^{-1}\right)$, $B$. Increase in $\mathrm{KCl}$ dosage to $300 \mathrm{~kg} \mathrm{KCl} \mathrm{ha}^{-1}, \mathrm{C}$. A + addition $20 \mathrm{~kg}$ ZincMicro ha $^{-1}$, and $D . B+$ addition $20 \mathrm{~kg}$ ZincMicro ha ${ }^{-1}$. The results showed that the application of $\mathrm{KCl}$ fertilizer with the addition of ZincMicro was able to reduce the severity of brown leaf spot disease (Cercospora henningsii). The addition of $\mathrm{KCl}$ and ZincMicro fertilizer was not able to reduce the incidence of tuber rot disease.

Keywords: Brown leaf spots, cassava, KCl, ZincMicro. 


\section{PENDAHULUAN}

Ubikayu merupakan salah satu komoditas tanaman penting untuk bahan baku industri setelah sawit dan karet. Ubikayu dapat diolah menjadi suatu produk untuk berbagai macam keperluan dalam bidang industri antara lain industri makanan, industri kertas dan industri tekstil. Selain itu, ubikayu juga dapat dimanfaatkan sebagai pakan ternak dan bahan baku bioetanol (Ditjentan, 2012).

Berdasarkan data Badan Pusat Statistik (BPS, 2018), provinsi Lampung menduduki peringkat pertama sebagai penghasil ubikayu terbesar di Indonesia dengan luas panen mencapai 208.662 ha dan total produksi ubikayu mencapai 5.451 .312 ton. Produksi tanaman ubikayu dari tahun 2013 sampai 2017 berturutturut adalah 8,$32 ; 8,03 ; 7,38 ; 6,48 ; 5,45$ juta ton. Data tersebut menunjukkan bahwa produksi tanaman ubikayu mengalami penurunan (BPS, 2018).

Salah satu penyebab penurunan hasil produksi tanaman ubikayu disebabkan oleh serangan patogen pada ubikayu. Terdapat beberapa penyakit penting pada tanaman ubikayu di Indonesia, yaitu penyakit bercak daun coklat (Cercospora henningsii), bercak daun baur (Cercospora viscosae), hawar bakteri (Xanthomonas campestris pv. manihotis), Layu bakteri (Pseudomonas solanacearum), mosaik virus (Cassava Mosaic Virus) dan busuk umbi (Abaca et al. 2014). Selain itu, faktor pembatas produksi ubikayu adalah ketersediaan unsur hara. Unsur hara esensial dapat digolongkan menjadi unsur hara makro dan mikro (Lakitan, 1993). Unsur hara makro yaitu unsur hara yang dibutuhkan tanaman dalam jumlah besar seperti karbon $(C)$, hidrogen $(H)$, oksigen $(O)$, nitrogen $(N)$, fosfor $(P)$, kalium $(K)$, kalsium $(\mathrm{Ca})$, magnesium (Mg), dan sulfur (S). Unsur hara mikro yaitu unsur hara yang dibutuhkan tanaman dalam jumlah kecil antara lain molibdenum (Mo), besi (Fe), boron (B), seng $(\mathrm{Zn})$, mangan $(\mathrm{Mn})$, tembaga $(\mathrm{Cu})$, khlor $(\mathrm{Cl})$, silikon $(\mathrm{Si})$, natrium $(\mathrm{Na})$, dan kobalt (Co).

Kalium (K) merupakan unsur hara utama ketiga setelah nitrogen dan fosfor. Jenis pupuk kalium yang biasanya digunakan yaitu $\mathrm{KCl}$. Kalium klorida $(\mathrm{KCl})$ merupakan salah satu jenis pupuk kalium yang termasuk pupuk tunggal. Menurut Aminuddin, Nurhayati dan Tambunan, (2006). kalium berfungsi sebagai struktur jaringan tanaman, mempertebal dinding sel epidermis dan sel kutikula sehingga dapat menghalangi penetrasi patogen, serta meningkatkan pembentukan hijau daun dan karbohidrat pada buah. Tanaman yang kekurangan kalium menyebabkan tanaman kerdil, fotosintesis terganggu, dapat mengurangi hasil produksi, dan rentan terhadap serangan penyakit. Kalium mempengaruhi mekanisme gerak menutup stomata, sehingga kalium yang cukup dapat mengurangi penetrasi penyakit melalui stomata dan meningkatkan ketebalan epidermis, sehingga dapat menghalangi penetrasi patogen.

Beberapa unsur hara mikro yang dibutuhkan oleh tanaman adalah unsur seng (Zn) yang berperan dalam aktivitor enzim, pembentukan klorofil, membantu proses fotosintesis, pemanjangan sel dan ruas batang, meningkatkan produktivitas tanaman, serta meningkatkan resistensi terhadap serangan organisme pengganggu tanaman (OPT). Selain itu, tembaga $(\mathrm{Cu})$ berfungsi untuk pertumbuhan tanaman, pembentukan klorofil dan ketahanan terhadap penyakit (Fauziah, Wulansari dan Rezamela, 2018).

Penelitian ini bertujuan untuk mengetahui pengaruh penambahan pupuk $\mathrm{KCl}$ dan ZincMicro terhadap keparahan penyakit bercak daun coklat (Cercospora henningsii), dan keterjadian penyakit busuk umbi pada tanaman ubikayu 


\section{METODE PENELITIAN}

Penelitian ini dilaksanakan di Desa Sukanegara, Kecamatan Tanjung Bintang, Kabupaten Lampung Selatan dan di Laboratorium Bioteknologi, Fakultas Pertanaian, Universitas Lampung. Pada bulan April 2018 hingga Februari 2019. Penelitian disusun dengan Rancangan tersarang (ulangan tersarang dalam perlakuan) yang terdiri dari 4 perlakuan, yaitu $\mathrm{A}$. dosis sesuai kebiasaan petani $\left(200 \mathrm{~kg} \mathrm{KCl} \mathrm{ha}^{-1}\right), \mathrm{B}$. peningkatan dosis $\mathrm{KCl}$ menjadi $\left(300 \mathrm{~kg} \mathrm{KCl} \mathrm{ha}^{-1}\right), \mathrm{C}$. $\mathrm{A}+$ penambahan $20 \mathrm{~kg}$ ZincMicro ha ${ }^{-1}$, D. B + penambahan $20 \mathrm{~kg}$ ZincMicro ha $^{-1}$.

\section{Pelaksanaan Penelitian}

\section{Persiapan lahan}

Lahan dibersihkan dari sisa-sisa tanaman sebelumnya, kemudian tanah diolah menggunakan mesin bajak. Pembajakan dilakukan dua kali dengan jarak kurang lebih satu minggu dari pembajakan pertama. Setelah lahan diolah, kemudian dilakukan pengukuran atau diploting seluas $3.120 \mathrm{~m}^{2}$ dan dibagi menjadi 24 petak satuan percobaan dimana satu petak percobaan dibuat dua lubang tanam dengan jarak tanam ubikayu dalam guludan $1 \mathrm{~m} \times 1 \mathrm{~m}$. Tinggi guludan $30 \mathrm{~cm}$, lebar $2 \mathrm{~m}$, panjang $80 \mathrm{~m}$, serta jarak antar guludan $1 \mathrm{~m}$.

\section{Penanaman}

Stek batang ubikayu yang digunakan adalah ubikayu klon BW-1 yang berasal dari tanaman sebelumnnya. Penanaman dilakukan secara monokultur dengan sistem double row. Stek batang berukuran panjang $25 \mathrm{~cm}$ dan rata-rata diameter batang $3 \mathrm{~cm}$. Bibit ditanam dengan cara menancapkan stek secara vertikal dengan kedalaman 5 sampai $10 \mathrm{~cm}$ atau sepertiga panjang batang tanaman masuk ke dalam tanah dengan arah mata tunas menghadap ke atas.

\section{Pemupukan}

Pemupukan dilakukan sebanyak 2 kali, yaitu pemupukan awal pada fase vegetatif dan pemupukan kedua pada fase generatif. Pemupukan pertama semua tanaman dipupuk dengan dosis sesuai kebiasaan petani yaitu $200 \mathrm{~kg}_{\text {urea ha }}{ }^{-1}, 150$ $\mathrm{kg} \mathrm{TSP} \mathrm{ha-1}$, dan $200 \mathrm{~kg} \mathrm{KCl} \mathrm{ha-1}$. Sedangkan pemupukan kedua sebagai perlakuan untuk setiap petak percobaan, yaitu pupuk $100 \mathrm{~kg} \mathrm{KCl} \mathrm{ha}^{-1}$ dan $20 \mathrm{~kg}$ Zincmicro ha-1. Pupuk diberikan ke tanaman dengan cara ditugal.

\section{Variabel yang Diamati}

\section{Pengamatan gejala penyakit}

Pengamatan gejala penyakit di lapangan dilakukan dengan melihat gejala luar secara visual dan saat pemanenan umbi yang terlihat bergejala diambil untuk dilakukan pengamatan lebih lanjut di laboratorium. Langkah-langkah yang dilakukan adalah isolasi, pemurnian, inokulasi dan identifikasi patogen.

\section{Isolasi}

Isolasi dilakukan setelah mendapatkan sampel umbi yang terserang patogen pada saat pemanenan. Sampel umbi yang terserang patogen dibawa ke laboratorium untuk dilakukan isolasi dengan menggunakan media PSA. 
Prosedur pembuatan media PSA satu liter dibutuhkan $200 \mathrm{~g}$ kentang, $20 \mathrm{~g}$ gula pasir, dan $20 \mathrm{~g}$ agar bubuk. Kupas kentang kemudian dicuci dan dipotong dadu kecil, lalu direbus dengan air akuades sebanyak 1 liter hingga kentang lunak. Air rebusan kentang kemudian disaring ke dalam erlenmeyer. Hasil saringan air rebusan kentang tersebut kemudian ditambahkan agar bubuk dan gula pasir, kemudian diaduk hingga homogen. Media PSA kemudian disterilisasi menggunakan autoklaf dengan suhu $121^{\circ} \mathrm{C}$ serta tekanan $1 \mathrm{~atm}$ selama \pm 15 menit. Setelah sterilisasi media dibiarkan sampai hangat kuku lalu ditambahkan asam laktat sebanyak $1,4 \mathrm{ml}$ dengan menggunakan mikropipet kemudian diaduk dan media tersebut dituangkan kedalam cawan petri.

Isolasi dilakukan dengan cara bagian umbi tanaman yang menunjukkan gejala penyakit (busuk) terlebih dahulu dicuci dengan air mengalir kemudian potong batas antara bagian umbi yang sehat dan sakit sebesar $\pm 1 \times 1 \mathrm{~cm}$, lalu di rendam dengan larutan $2 \% \mathrm{NaClO}$ selama $30-60$ detik. Selanjutnya dibilas dengan akuades dan dikeringkan atas tisu lalu diisolasikan secara aseptik pada media PSA dan diinkubasi pada suhu ruangan. Setelah jamur tumbuh, kemudian dimurnikan. Untuk mendapatkan biakan murni dilakukan dengan mengambil hifa dengan menggunakan jarum ent lalu ditumbuhkan pada media PSA.

\section{Inokulasi}

Inokulasi dilakukan secara aseptik dengan cara lukai bagian umbi sehat yang akan di inokulasi dengan menusuknya menggunakan jarum steril. Kemudian biakan murni hasil isolasi ditempelkan ke bagian yang telah dilukai, selanjutnya di bagian tersebut diwapping agar biakan murni menempel dibagian umbi yang telah dilukai. Kemudian umbi diletakkan di atas nampan yang telah diberi tisu kering yang dibasahi dengan air, di atas permukaan tisu diberi rantingan kayu yang telah diautoklaf sebagai penyangga agar umbi tidak menempel dengan tisu.

\section{Identifikasi patogen}

Identifikasi patogen bercak daun coklat dilakukan dengan cara daun yang menunjukkan gejala bercak daun coklat dikorek mengunakan jarum yang steril, kemudian diletakan diatas kaca preparat lalu diamati di bawah mikroskop. Identifikasi patogen busuk umbi dilakukan dengan cara, hasil isolat yang telah ditumbuhi biakan jamur selama 7 hari, diidentifikasi di bawah mikroskop dan diamati ciri-ciri mikroskopisnya.

\section{Pengamatan intensitas penyakit tanaman ubikayu}

Intensitas penyakit diukur dengan menghitung keparahan penyakit dan keterjadian penyakit. Untuk bercak daun coklat dihitung menggunakan rumus keparahan penyakit, sedangkan busuk umbi dihitung menggunakan keterjadian penyakit.

Keparahan penyakit bercak daun coklat dihitung berdasarkan pengamatan gejala penyakit, setiap barisnya diamati 4 sampel tanaman ubikayu, sehingga diperoleh 24 sampel tanaman per perlakuan. Pengamatan dilakukan setiap 2 minggu. Untuk mempermudah pengamatan dan penentuan skor kerusakan, maka dibuat kriteria seperti pada (Tabel 1) dan keparahan penyakit bercak daun coklat dihitung dengan rumus berikut (Ginting, 2013). 


$$
\mathrm{PP}=\frac{\sum(n \times v)}{Z \times N} \times 100 \%
$$

Keterangan:

PP : keparahan penyakit (\%)

$\mathrm{n}$ : jumlah daun yang memiliki kategori skala kerusakan yang sama

$\mathrm{v}$ : skor kerusakan dari tiap kategori serangan

$\mathrm{N}$ : jumlah daun yang diamati

Z : skor skala tertinggi

Tabel 1. Skor keparahan penyakit

\begin{tabular}{cll}
\hline Skor & Keterangan & Tingkat Serangan \\
\hline 0 & Tidak terdapat gejala & Tanaman sehat \\
1 & Gejala timbul sampai 10\% luas/volume daun & Ringan \\
2 & Gejala terjadi pada lebih 10\% sampai 25\% daun & Agak parah \\
3 & Gejala terjadi pada lebih 25\% sampai 50\% daun & Parah \\
4 & Gejala terjadi pada lebih 50\% atau tanaman mati & Sangat parah \\
\hline
\end{tabular}

Keterjadian penyakit busuk umbi dilakukan untuk mengitung jumlah umbi yang menunjukkan gejala dan jumlah seluruh umbi yang diamati. Nilai keterjadian penyakit dihitung menggunakan rumus sebagai berikut (Ginting, 2013):

$\mathrm{TP}=(\mathrm{n} / \mathrm{N}) \times 100 \%$

Keterangan:

TP: keterjadian penyakit (\%)

$\mathrm{n}$ : jumlah umbi yang terserang penyakit

$\mathrm{N}$ : jumlah seluruh umbi yang diamati

\section{HASIL DAN PEMBAHASAN}

\section{Penyakit Bercak Daun Coklat}

Gejala bercak daun coklat berbentuk bulat, berwarna coklat dan berukuran kecil, bagian sisi atas bercak tampak coklat merata dengan tepi gelap yang jelas, sedangkan bagian bawah daun bercak kurang jelas dan di tengah nya terdapat warna keabu-abuan yang merupakan konidia dari jamur (Gambar 1).

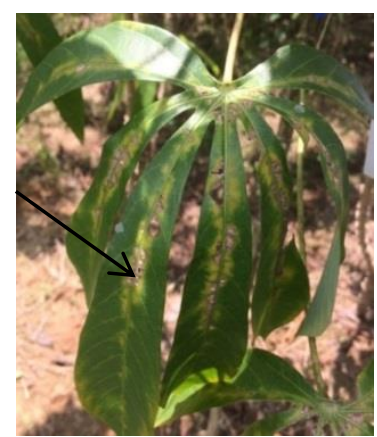

Gambar 1. Gejala penyakit bercak daun coklat. 
Hasil pengamatan laboratorium menunjukkan bahwa bercak daun coklat disebabkan oleh Cercospora henningsii. Konidia jamur berbentuk tabung lurus dengan kedua ujungnya membulat tumpul dan mempunyai sekat 2 - 8 (Gambar 2). Menurut Semangun (2004) struktur patogen yang ditemukan merupakan struktur jamur Cercospora henningsii.

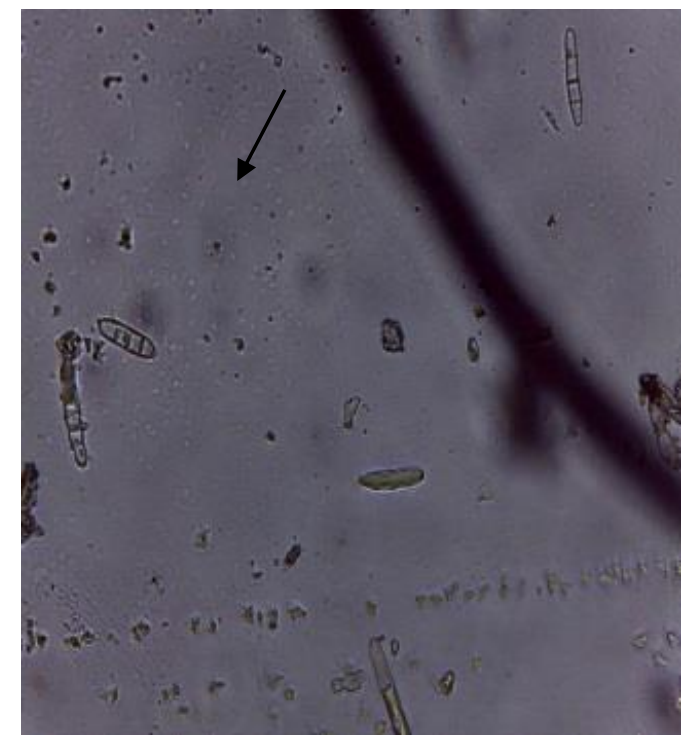

Gambar 2. Konidia jamur Cercospora henningsii pada perbesaran 40x.

Keparahan penyakit bercak daun coklat dipengaruhi oleh perlakuan penambahan pupuk $\mathrm{KCl}$ dan ZincMicro (Tabel 1). Perlakuan peningkatan dosis menjadi $300 \mathrm{~kg} \mathrm{KCl} \mathrm{ha-1}$ tidak berbeda nyata dengan perlakuan dosis sesuai kebiasaan petani $\left(200 \mathrm{~kg} \mathrm{KCl} \mathrm{ha}^{-1}\right)$ dengan demikian penambahan dosis $100 \mathrm{~kg} \mathrm{KCl}$ $\mathrm{ha}^{-1}$ tidak berpengaruh terhadap keparahan penyakit bercak daun coklat. Perlakuan dosis sesuai kebiasaan petani $\left(200 \mathrm{~kg} \mathrm{KCl} \mathrm{ha}^{-1}\right)$ dan penambahan $20 \mathrm{~kg}$ ZincMicro $\mathrm{ha}^{-1}$ menunjukkan hasil berbeda nyata dengan perlakuan yang hanya diberi pupuk $\mathrm{KCl}$, berarti tanaman yang ditambahkan pupuk ZincMicro memiliki keparahan penyakit bercak daun lebih rendah dibandingkan dengan tanaman yang hanya diberi pupuk KCl. Perlakuan dosis sesuai kebiasaan petani $\left(200 \mathrm{~kg} \mathrm{KCl} \mathrm{ha}^{-1}\right)$ dan penambahan $20 \mathrm{~kg}$ ZincMicro $\mathrm{ha}^{-1}$ tidak berbeda nyata dengan perlakuan peningkatan dosis menjadi $300 \mathrm{~kg} \mathrm{KCl} \mathrm{ha}^{-1}$ dan penambahan $20 \mathrm{~kg}$ ZincMicro ha ${ }^{-1}$ dengan demikian penambahan $100 \mathrm{~kg} \mathrm{KCl} \mathrm{ha}^{-1}$ tidak berpengaruh terhadap bercak daun coklat.

Hasil penelitian terlihat bahwa pemberian tambahan pupuk ZincMicro mampu menekan serangan Cercospora henningsii pada bercak daun coklat tanaman ubikayu. Hal ini berarti tanaman yang diberi tambahan ZincMico memiliki ketahanan terhadap serangan patogen. Di dalam pupuk ZincMicro terkandung unsur hara Fe, $\mathrm{Mn}, \mathrm{B}, \mathrm{Zn}, \mathrm{Cu}, \mathrm{Co}$, dan Mo. Salah satu kandungan unsur hara mikro yang diaplikasikan yaitu unsur mangan. Mangan (Mn) berfungsi sebagai dalam pembentukan klorofil, membantu proses fotosintesa, serta sebagai pendukung aktivitas enzim salah satunya enzim peroksidae. Menurut penelitian Marwan (2014), aktivitas enzim peroksidae berperan penting dalam penguatan dinding sel tanaman, sehingga dapat meningkatkan ketahanan tanaman terhadap serangan patogen. 
Tabel 2. Keparahan penyakit bercak daun coklat pada tanaman ubikayu dengan penambahan pupuk KCl dan ZincMicro

Perlakuan

\section{Keparahan penyakit (\%)}

\begin{tabular}{ll}
\hline A & $17,11 \mathrm{a}$ \\
B & $17,41 \mathrm{a}$ \\
C & $13,57 \mathrm{~b}$ \\
D & $14,73 \mathrm{~b}$ \\
\hline
\end{tabular}

\section{BNT 5\%} 1,58

Keterangan: Angka-angka yang diikuti dengan huruf yang sama menunjukkan tidak berbeda nyata (uji BNT 5\%), A. dosis sesuai kebiasaan petani (200 kg KCl ha ${ }^{1}$ ), B. peningkatan dosis $\mathrm{KCl}$ menjadi $300 \mathrm{~kg} \mathrm{KCl} \mathrm{ha}^{-1}, \mathrm{C}$. A + penambahan 20 $\mathrm{kg}$ ZincMicro ha ${ }^{-1}$, D. B + penambahan $20 \mathrm{~kg}$ ZincMicro ha $^{-1}$.

Gejala busuk umbi yang ditemukan di lapangan berupa busuk pada sebagian dan seluruh bagian umbi, terdapat benang miselia berwarna putih pada pangkal batang (tidak semua ada) (Gambar 3A), ditemukan umbi berbau busuk dan teksturnya lembek (Gambar 3B), saat digali di sekitar umbi yang busuk terdapat beberapa jenis arthropoda tanah yaitu ulat, uret, rayap (Gambar $\mathbf{3 C}$ ).
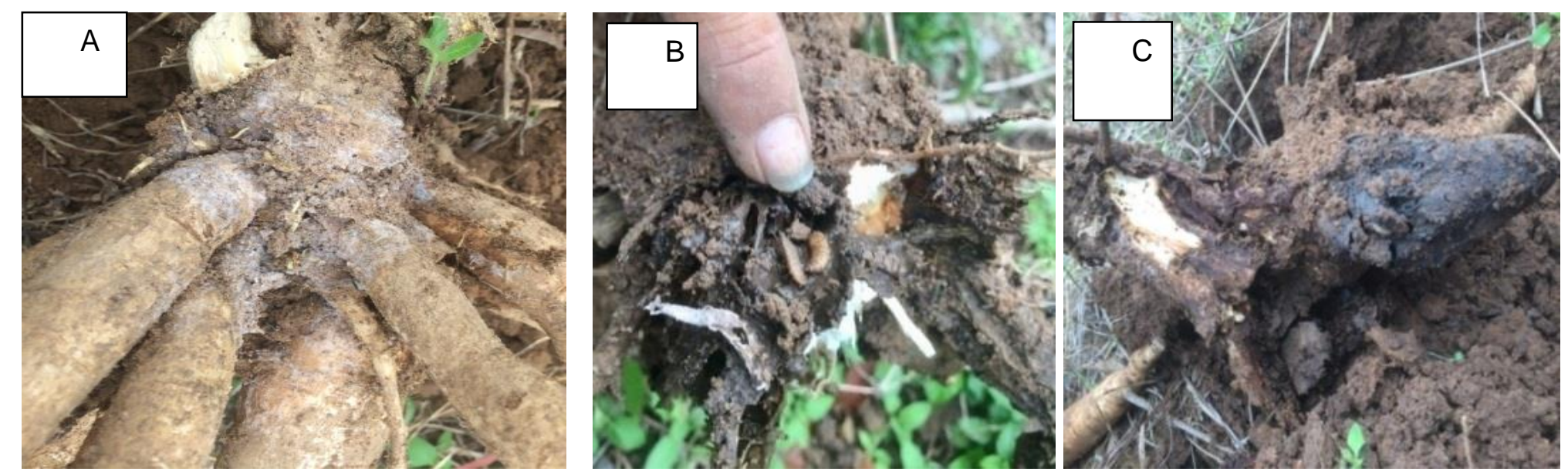

Gambar 3. Miselium jamur pada pangkal batang ubikayu (A), gejala penyakit busuk umbi (B), arthropoda tanah (ulat) yang ditemukan di sekitar umbi yang busuk (C).

Pengamatan di laboratorium, umbi bergejala yang telah diisolasi pada media PSA, awalnya berwarna putih kemudian berubah menjadi hitam (Gambar 4). Hal ini sama dengan hasil isolasi yang didapatkan oleh Thongkham dan Soytong (2016), yaitu jamur Neoscytalidium sp.

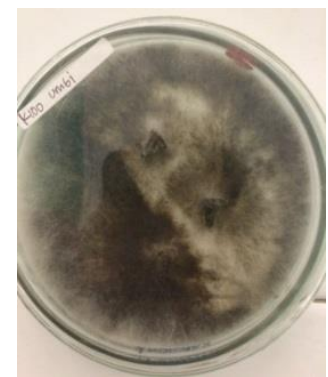

Gambar 4. Koloni jamur hasil isolasi umur 7 hari 
Hasil pengamatan mikroskopis di laboratorium dengan perbesaran mikroskop 40x, isolat ini memiliki hifa bercabang dan bersekat (Gambar 5A), konidia berbentuk tabung (Gambar 5B), serta adanya arthrokonidia (Gambar 5C).
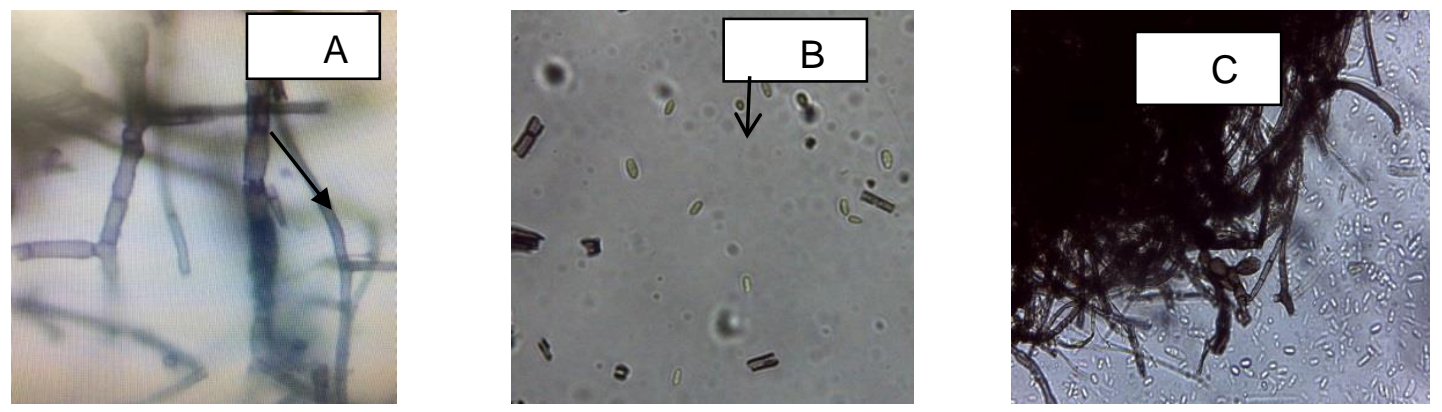

Gambar 5. Pengamatan mikroskopis perbesaran 40x, hifa bercabang dan bersekat (A), bentuk konidia (B), adanya arthrokonidia (C) .

Berdasarkan hasil isolasi dan pengamatan mikroskopis yang telah dilakukan diperoleh hasil yang serupa dengan hasil penelitian Thongkham dan Soytong (2016), yaitu jamur Neoscytalidium sp.

Hasil inokulasi menunjukkan bahwa gejala mulai tampak pada bagian umbi 2 minggu setelah inokulasi. Gejala yang tampak sama dengan gejala yang ditemukan di lapangan. Gejala awal terlihat sebagai titik hitam kecil pada bagian umbi, selanjutnya gejala berkembang dan busuknya semakin membesar (Gambar 6). Menurut Saleh, Harnowo dan Mejaya (2016) penyakit busuk umbi disebabkan oleh jamur yang masuk melalui luka yang terjadi pada saat pemeliharaan ataupun luka akibat serangga.

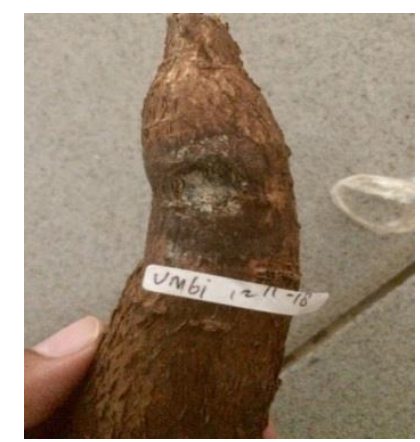

Gambar 6. Hasil inokulasi

Berdasarkan pengamatan yang telah dilakukan, diduga penyebab penyakit busuk umbi yang menyerang tanaman ubikayu di Tanjung Bintang disebabkan oleh Neoscytalidium sp.

Berdasarkan hasil analisis ragam, keterjadian penyakit busuk umbi tidak dipengaruhi secara nyata oleh penambahan pupuk KCl dan ZincMicro (Tabel 3). 
Tabel 3. Keterjadian penyakit busuk umbi pada tanaman ubikayu dengan penambahan pupuk KCl dan ZincMicro

\begin{tabular}{cc}
\hline Perlakuan & Keterjadian penyakit (\%) \\
\hline A & 28,99 \\
B & 25,34 \\
C & 22,55 \\
D & 16,34 \\
\hline
\end{tabular}

Keterangan: A. dosis sesuai kebiasaan petani $\left(200 \mathrm{~kg} \mathrm{KCl} \mathrm{ha}^{-1}\right)$, B. peningkatan dosis $\mathrm{KCl}$ menjadi $300 \mathrm{~kg} \mathrm{KCl} \mathrm{ha}^{-1}$, C. A + penambahan $20 \mathrm{~kg} \mathrm{ZincMicro} \mathrm{ha}^{-1}, \mathrm{D} . \mathrm{B}+$ penambahan $20 \mathrm{~kg}$ ZincMicro ha ${ }^{-1}$.

\section{SIMPULAN}

Berdasarkan penelitian yang telah dilakukan dapat disimpulkan bahwa: Pupuk $\mathrm{KCl}$ dengan penambahan ZincMicro mampu menekan keparahan penyakit bercak daun coklat (Cercospora henningsii) tanaman ubikayu. Penambahan pupuk KCl dan ZincMicro tidak mampu menekan keterjadian penyakit busuk umbi tanaman ubikayu.

\section{DAFTAR PUSTAKA}

Abaca, A., Kiryowa, M., Awori, E.,Andema, A., Dradiku, F., Moja, A.S., and Mukalazi, J. 2014. Cassava pest and diseases, prevalence and performance asrevealed by adaptive trial sites in Nourth Western Agro-Ecological Zone of Uganda. Journal of Agricultural Science 6(1): 116-122.

Aminuddin, M.I., Nurhayati., Tambunan N.O. 2006. Pengaruh pupuk kalium terhadap penyakit gugur daun Corynespora pada pembibitan karet. Seminar Nasional Pengelolaan OPT Yang Berwawasaan Lingkungan. 96-102 hlm.

Badan Pusat Statistik (BPS). 2018. Statistik Daerah Provinsi Lampung (https://www.bps.go.id). Diakses pada 29 September 2018.

Ditjentan. 2012. Pedoman teknis pengelolaan produksi ubikayu," Direktorat Jendral Tanaman Pangan. Kementrian Pertanian, Jakarta, $485 \mathrm{hlm}$.

Fauziah, F., Wulansari, R., dan Rezamela, E. 2018. Pengaruh pemberian pupuk mikro $\mathrm{Zn}$ dan $\mathrm{Cu}$ serta pupuk tanah terhadap perkembangan Empoasca sp. pada areal tanaman teh. Jurnal Agrikultura 2(10): 26-34.

Ginting, C. 2013. IImu Penyakit Tumbuhan (Konsep dan Aplikasi). Lembaga Penelitian Universitas Lampung, Bandar Lampung, $203 \mathrm{hlm}$.

Lakitan, B. 1993. Dasar-dasar Fisiologi Tumbuhan. akarta: PT Raja Grafindo Persada. $204 \mathrm{hlm}$.

Marwan, H. 2014. Pengimbasan ketahanan tanaman pisang terhadap penyakit darah (Ralstonia solanacearum Phylotipe IV) menggunakan bakteri endofit. Jurnal Hama dan Penyaki Tumbuhan Tropika 14(2): 128-135.

Saleh, N., Harnowo, D., dan Mejaya, I.J.M. 2016. Penyakit-penyakit penting pada ubikayu: deskripsi, bioekologi dan pengendaliannya. Balai Penelitian Tanaman Aneka Kacang dan Umbi. Malang. $168 \mathrm{hlm}$.

Semangun, H. 2004. Penyakit-Penyakit Tanaman Pangan Di Indonesia. Gadjah Mada University Press, Yogyakarta, $850 \mathrm{hlm}$. 
Thongkham, D dan Soytong, K. 2016. Isolation, Identification, and Pathogenicity Test from Neoscytalidium dimidiatum Causing Stem Canker of Dragon Fruit. International Journal of Agricultural Technology 12(7.2): 2187-2190. 